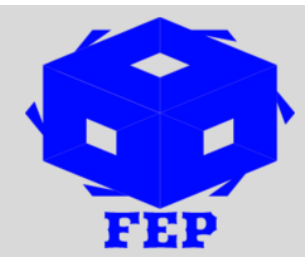

\title{
EFFECT OF ALMOND SHELL PARTICLES ON TENSILE PROPERTY OF PARTICLEBOARD
}

Isselem Arbih Ethmane ${ }^{1} \&$ Ahmed Yahfdhou ${ }^{2}$

${ }^{1,2}$ Faculty of Chemistry, Udayana University, Indonesia

*Corresponding Author: Isselem Arbih Ethmane

Article Received: 09-10-19

Accepted: 21-01-20

Published: 05-02-20

Licensing Details: Author retains the right of this article. The article is distributed under the terms of the Creative Commons Attribution-Non Commercial 4.0 License (http://www.creativecommons.org/licences/by-nc/4.0/) which permits non-commercial use, reproduction and distribution of the work without further permission provided the original work is attributed as specified on the Journal open access page.

\section{ABSTRACT}

The objective of the study was to fabricate particleboard using almond shell. The significance of the study is that it can result in creating raw material for panel industry which is in shortage these days. Different particleboards were made based on almond shell particles ratios mixed with epoxy resin. In this study, we investigated the resulting shell particleboard tensile properties. Results shows that when added with almond shell, the tensile properties of the resulting panel showed greater performance. For example, it showed better hardness which is a desirable quality.

Keywords: Resin, Almond Shell, Mechanical Properties, Particleobard

\section{INTRODUCTION}

Every year, there are almost 13 million hectare area of forests declining resulting in decrease in wood production and increase in demand for alternative materials (Ashore, 2006; Tewari, Singh, Gope, and Arun, 2012). In the production of particleboard, there is greater preference for using the agricultural residues because of better economic value and greater concern for environmental issues. The history of industrial age shows that there was greater use of agricultural resides in particleboard and trend is increasing. Commercial manufacturing of different panels including crop residues, wheat, bagasse are now common in some countries (Copur, Guler, Akgul, and Tascioglu, 2007). Some studies investigated the feasibility of biomass for particleboard manufacturing for residuals including almond shell, pine cone, peanut hull, and hazelnut hust (Tewari, et al., 2012; Copur, et al., 2007; Guler, et 
al., 2008). The other dimension of the use of agricultural residual in industrial manufacturing is that it can help in safeguarding the future of forest industry because of bringing reduction in demand for wood. Almond shell, an agricultural residue is the ligno-cellulosic material forming the thick endocarp or husk of the almond fruit that upon processing to obtain the edible seeds is separated and is normally dumped due to the no industrial usage (Urrestarazu \& Martinez, 2005). If it is burned, it can cause environmental problems such as pollution or soil erosion. While, making it usable in industrial production can be environmentally friendly and can create a source of income for the farmers. Thus, keeping this context in mind, the current study investigates the suitability of almond shell particles in production of particleboard as supplement. In this study, the chemical properties of the almond shell made particle board is investigated.

\section{MATERIALS AND METHODS}

In present study, we used almond shell which was obtained locally. Once collected, the almond shell was dried in sun for one day and then made to cut in smaller pieces. Later, Wiley mill was used for converting it into smaller particles as provided in figure 2 . The particle size was maintained within given range using the ASTM 40 and ASTM 80 number of sieve. Epoxy resin (CY230), hardener (HY951) and almond shell particles with different weight percentage were used. Using the mechanical stirring at $3000 \mathrm{rpm}$, different weight percentage of almond shell $(10,15,20,25,30 \mathrm{wt} \%)$ and epoxy resin were mixed.

The resulting solution was obtained by mixing almond shell particles in resin which was kept in the furnace for two hours under temperature of $90 \pm 10^{\circ} \mathrm{C}$. After interval of 30 minutes, the solution was removed from the furnace and remixed by mechanical stirrer at same speed. The whole solution was taken out after two hours and allowed to cool at a temperature of $45^{\circ} \mathrm{C}$. In situation when we reached to the temperature of $45 \mathrm{C}$, the hardener HY951 (10 weight percentage) was mixed immediately. Because of hardener addition, high viscous solution was obtained and poured into different molds of $46 \mathrm{~mm} \times 46 \mathrm{~mm} \times 10 \mathrm{~mm}$ for sample preparation. T. ensile tests were conducted on $100 \mathrm{kN}$ servo hydraulic universal testing machine (ADMET, USA) under displacement mode of control of $1 \mathrm{~mm} / \mathrm{min}$

\section{Tensile strength}

\section{RESULTS AND DISCUSSION}

$100 \mathrm{KN}$ ADMET make servo controlled universal testing machine was used for determining the mechanical properties of the almond shell particles. Table 1 present the properties of various percentage of almond shell particles along with that of epoxy resign. 
Table 1: Tensile properties of the almond shell particles based composite materials.

\begin{tabular}{|l|l|l|l|l|l|}
\hline Property & $\begin{array}{l}10 \% \text { almond } \\
\text { shell particles }\end{array}$ & $\begin{array}{l}15 \% \text { almond } \\
\text { shell particles }\end{array}$ & $\begin{array}{l}20 \% \text { almond } \\
\text { shell particles }\end{array}$ & $\begin{array}{l}25 \% \text { almond } \\
\text { shell particles }\end{array}$ & $\begin{array}{l}30 \% \text { almond } \\
\text { shell particles }\end{array}$ \\
\hline $\begin{array}{l}\text { Modulus of } \\
\text { elasticity, E (MPa) }\end{array}$ & 2752 & 2702 & 2532 & 2397 & 2299 \\
\hline $\begin{array}{l}\text { Ultimate stress } \\
\text { (MPa) }\end{array}$ & 37.27 & 33.57 & 32.29 & 29.94 & 27.24 \\
\hline
\end{tabular}

The results shows that significant difference can be observed on the ultimate tensile strength of the composite material having various wt $\%$ of almond shell particles. The lowest tensile strength is 27.24 wt\% almond shell particle with composition of $2299 \mathrm{MPa}$. In situation, when almond shell particles are reduced to $10 \mathrm{wt} \%$, the value of the ultimate strength increases and reaches to the $37.27 \mathrm{MPa}$. The reduced ultimate strength is because of increase in almond shell particle contents and because of pure binding with the epoxy and voids present in the material.

The results shows that significant differences can be observed in the behavior of mechanical properties because of addition of different wt $\%$ of almond shell particles in epoxy resin.

The result leads to this conclusion that effect of weight fraction $\left(\mathrm{V}_{\mathrm{f}}\right)$ on modulus of elasticity and ultimate strength can be described in equation 1 and 2 with a correlation coefficient greater than 0.99 .

Modulus of Elasticity $(\mathrm{MPa})=-12.828 \mathrm{~V}_{\mathrm{f}}^{2}-15.728 \mathrm{~V}_{\mathrm{f}}+1583.2$

Ultimate Strength $(\mathrm{MPa})=0.1383 \mathrm{~V}_{\mathrm{f}}^{2}-3.5047 \mathrm{~V}_{\mathrm{f}}+40.442$

\section{CONCLUSIONS}

The focus of the study was to investigate the suitability of almond shell particles for producing the particleboard. Results indicate that when almond shell particles are added, the mechanical properties of the particleboard are highly influenced. With increase of percentage of almond particles, the modulus of elasticity decreases. When further almond particles are added, the ultimate tensile stress with addition of almond particles. The benefit of using almond shell in particleboard production is that it has greater positive influence on natural environment and also bring some extra income for farmers.

\section{References}

Ashori, A. (2006). Nonwood fibers-A potential source of raw material in papermaking. Polymer-Plastics Technology and Engineering, 45(10), 1133-1136. 
Ayrilmis, N., Buyuksari, U., Avci, E., \& Koc, E. (2009). Utilization of pine (Pinus pinea L.) cone in manufacture of wood based composite. Forest Ecology and Management, 259(1), 65-70.

Buyuksari, U., Ayrilmis, N., Avci, E., \& Koc, E. (2010). Evaluation of the physical, mechanical properties and formaldehyde emission of particleboard manufactured from waste stone pine (Pinus pinea L.) cones. Bioresource technology, 101(1), 255259.

Chaudhary, A. K., Gope, P. C., \& Singh, V. K. (2013). Effect of almond shell particles on tensile property of particleboard. J. Mater. Environ. Sci, 4, 109-112.

Çöpür, Y., Güler, C., Taş̧̧ığlu, C., \& Tozluoğlu, A. (2007). Incorporation of hazelnut shell and husk in MDF production. Bioresource Technology, 99(15), 7402-7406.

Guler, C., Copur, Y., \& Tascioglu, C. (2008). The manufacture of particleboards using mixture of peanut hull (Arachis hypoqaea L.) and European Black pine (Pinus nigra Arnold) wood chips. Bioresource Technology, 99(8), 2893-2897.

Nemli, G., Y1ldız, S., \& Gezer, E. D. (2008). The potential for using the needle litter of Scotch pine (Pinus sylvestris L.) as a raw material for particleboard manufacturing. Bioresource Technology, 99(14), 6054-6058.

Pirayesh, H., \& Khazaeian, A. (2012). Using almond (Prunus amygdalus L.) shell as a biowaste resource in wood based composite. Composites Part B: Engineering, 43(3), 1475-1479.

Urrestarazu, M., Martínez, G. A., \& del Carmen Salas, M. (2005). Almond shell waste: possible local rockwool substitute in soilless crop culture. Scientia Horticulturae, 103(4), 453-460. 